\title{
Rethinking Materiality, Memory and Identity
}

TRACY IRELAND AND JANE LYDON

$\mathrm{T}$

This special issue of Public History Review considers how places, landscapes, remains and objects - in the past and in the present produce identity and memory. The material world both reflects and shapes sensory, affective and embodied experiences of memory and identification. Current thinking about heritage and the archaeology of the recent past challenges archaeological paradigms, advocating a new, ethnographic approach centred on the meaning of the past and its remains in the present. This work opens up an exciting new space for discussion and debate about archaeological, historical and heritage work concerned with memory and identity.

Vol 23 (2016): 1-8

ISSN: $1833-4989$

() 2016 by the author(s). This is an Open Access article distributed under the terms of the Creative Commons Attribution 4.0 International (CC BY 4.0) License (https://creativecommons.org/licenses/ by/4.0/), allowing third parties to copy and redistribute the material in any medium or format and to remix, transform, and build upon the material for any purpose, even commercially, provided the original work is properly cited and states its license. 


\section{THE MATERIAL TURN}

This volume contributes to a distinctively object-oriented approach within archaeology and heritage that focuses on the relationship between people and things. The recent 'material turn' may at first sight appear all too familiar to archaeologists: after all, its emphasis on the ways that material things and places shape human life have been known to the discipline since the 1970s via the work of scholars associated with the anthropologically-inspired approach of Daniel Miller, who have argued that things make us as much as we make things.' The concept of things possessing social lives of their own has been deployed in the concept of 'object biographies'. ${ }^{2}$ Such analyses also help us understand the materiality of the object and how its effects upon the human subject may be seen as another, crucial stage in its life story. Igor Kopytoff's object biography approach continues to be applied in tracing the 'life' of an object from its manufacture across its various uses, exchanges and effects. There is an enduring fascination in exploring the life of objects. ${ }^{3}$

However, over the last decade or so, an anthropologically-informed approach to knowledge construction has focused more explicitly on the active role of the non-human in shaping life, an interest that signals a shift in analysis from what things or images mean, to what they $d o{ }^{4}$ Instead of focusing on the semiotic or social meaning given to things, many scholars across a range of disciplines are now exploring the social effects of the material, regarding things as actors in a social field that makes no distinction between human and non-human actants.

Most often associated with a posthumanist approach derived from Latour's Actor Network Theory, an effect of this approach is to de-centre human agency and explore how meaning and effectivity is constituted across networks that include non-human actors. It has been taken up by those concerned with breaking down the Cartesian opposition between nature and culture, tangible and intangible, subject and object.5 Critiques of humanism and Cartesian dualisms that ground it have argued that all distinctions between the material and the social are the effect of technosocial practices, rather than the reflections of an underlying ontological reality. This reorientation, sometimes termed the 'new materialism', conceives of 'matter itself as lively or as exhibiting agency', and allows us to see human action and history within active processes of materialization. ${ }^{\text {In }}$ attempting to overcome the enduring separation between thing and meaning, concrete and abstract, physical and mental, scholars have sought to re-focus attention on the materiality of social life and to show that the relationship between people and things is mutually constitutive.' In questioning distinctions between objects and ideas, 
concepts and things, new methodologies are emerging that promise to overcome the traditional separation between fieldwork and analysis. ${ }^{s}$

This renewed concern with materiality can also be traced in recent literature and art, particularly since the late 1990s. Zuzanna Jakubowski has suggested that although this is often interpreted as a reaction to the rise of the digital, and a yearning for the authenticity of the 'real', she sees these avant-garde forms of realism as seeking to constitute an affective experience in themselves, rather than a representation of reality. Diverse recent works such as Orhan Pamuk's The Museum of Innocence, the loving family chronicle of Edmund de Waal's The Hare with the Amber Eyes, to the Marxist speculative materialism of China Mieville's novels, all freely delve into the affective economy of objects. In discussing Orhan Pamuk's focus on mass produced, every day objects, such as salt shakers and ashtrays, in the Museum of Innocence, Jakubowski suggests that this 'illustrates the Latourian democratic creation of meaning and reality by human and non-human actors alike - the salt shakers might be man-made but at the same time they possess a life of their own'.10

Roland Barthes' 1968 essay 'The Reality Effect' linked the rise of literary realism and materialism in the nineteenth century - for example, authors such as Balzac and Flaubert - with the contemporaneous rise of a range of realist practices, including 'objective history', and materialist practices, such as photography, archaeology, tourism and museum collecting, where materials were collected to produce a world-ordering narrative." Aligning this new interest in the material with the nonrepresentational allows us to make a link between the preoccupations of the 'new materialism' and emerging new approaches to heritage, archaeology and collecting practices, which move away from humancentred world ordering, to explore the embodied, affective experience of material and social worlds.

\section{EMOTIONAL PASTS}

A concern with materiality joins with the recent scholarly interest in the history, political effects and cultural role of emotions." Sometimes termed the 'affective turn', such research has defined emotions, or 'felt judgements', as embodied feelings experienced in the context of cultural values and principles. ${ }^{13}$ This field is premised on the argument that emotions, including their bodily dimensions, are culturally and historically determined, rather than biologically based and common to all humans. Although they have a neurological basis, they are learned 
and expressed in different ways according to social and temporal context.

In this view, emotions are as important in understanding the past as other social categories such as class, race and gender. They may be collective, historically created and locally contingent, and respond dynamically to circumstance, response or refusal in systems of circulation and exchange that Sara Ahmed terms 'emotional economies'. ${ }^{14}$ Such practices constitute 'objects of feeling' - those toward whom we feel pity, anger or love. ${ }^{15}$ An interest in emotions emerged in the context of broad theoretical shifts such as postmodernism with its scepticism toward grand narratives, self-reflexivity in interpretation, a related emphasis on language and discourse and a concern with gender and power in the reconstruction of past societies. ${ }^{16}$

In our own time, a politicised commitment to exploring inequality, and to understanding our own 'positioned subjectivity', may also constitute a productive source of critical engagement, including approaches such as 'auto-ethnography' that have allowed us to scrutinise our methodological and theoretical presuppositions and procedures, and myriad, otherwise overlooked aspects of archaeological, historical and heritage praxis. In addition, a focus upon our own engagement with the stuff we study contributes to our understanding of materiality: for example, in helping us understand relationships between humans and the material world through devices such as object biographies. Such processes may challenge Western ontologies and transcend traditional Western oppositions, such as the division between object and meaning. Finally, such an approach forces us to re-visit longstanding historiographical questions of empathy and its place as a heuristic device in understanding others.

Such concerns are linked to the anthropology of archaeology, sparked by an interest in the socio-political context of knowledge production that began during the 1970s. Such studies argued that science is not an objective set of techniques or principles but rather a culture, and that the objects of scientific study are socially constructed." Archaeologists have long argued for attending to their own disciplinary culture, especially in conducting fieldwork. Lynn Meskell notes that attention to the hybrid communities and discourse around such research de-centres 'the past' as a privileged locale and re-orients analysis in terms of the present and 'how archaeology works in the world' ${ }^{18}$ As Tracy Ireland's contribution to this collection insists, our response to heritage objects relies upon a 'visual code of authenticity' and on a history or narrative framework that is intimately related to political cultures. However, we must also recognize our identification with the 
sensuous and exotic past has its limits.

\section{The PAST in The PRESent}

Merging heritage and ethnographic practices allows the exploration of the meaning of the past in the present, the politics of practice and contemporary debates focused on the material traces of the past. In their discussion of archaeological ethnography, Hamilakis and Anagnostopoulos emphasise the significance of this approach in challenging the assumptions and authority of 'conventional' archaeology, and acknowledging a diverse range of interests in and ways of comprehending and narrating the past..$^{19}$ Attention to the finegrained experience of fieldwork - or 'deep hanging out', to use Clifford Geertz's phrase - shows how 'humans, non-humans, things, and their places of encounter become the context in which archaeological knowledge is co-created and produced' ${ }^{20}$

Steve Brown's contribution to this issue is a wonderful example of a lovingly detailed autoethnographic exploration of identity and belonging. He explores the phenomena of identity from my perspective of home and memory as experiences elicited, provoked, invoked and creatively imagined through encounter and entanglement with the "field site" and "found objects"'. Steve explores his identity as an archaeologist and how it is constituted within entangled webs of relationships with places and things that give meaning to his understanding of his own personal heritage.

In contrast, Erin Gibson ventures out to explore how memory is accumulated around place, as the indigenous Stl'atl'imx (pronounced Stat-lee-um) people of the lower Lillooet River Valley, in British Columbia, Canada, aim to preserve a colonial wagon route as a strategy for decolonizing and reclaiming their traditional territory and identity. She also looks in detail at the road's importance to a group of Grade 10 students who experience the wagon trail as part of a high school excursion, focusing on how the embodied experience of moving through this landscape is incorporated into their understandings of their own identity and their own future.

Tracy Ireland gets 'up close and personal' with two archaeological sites conserved in situ, comparing the 'Big Dig' archaeological site conserved in situ in Sydney, Australia, with the Pointe-à-Callière Musée d'archéologie et d'histoire in Montreal, Canada, in order to explore how these material encounters appear to 'create stable objects of memory and identity from a much more contingent and complex matrix of politics, social structures, and the more-than-human materiality of the city'. In 
particular, she argues that understanding heritage 'as a material structure for the "accumulation of affect"', and of how people feel heritage and the past through aesthetic and sensuous experiences of materiality and authenticity, bring us closer to understanding how heritage is seen to sustain identity and memory.

In contrast to the previous articles which focus on the sensuous materiality of archaeological remains and fieldwork in their many forms, Jane Lydon considers the webs of relationships that enmesh significant early photographs of Australian Indigenous people, arguing that through their materiality they exert a living power for descendants and for the nation as a whole. She charts the transformation of collections from anthropological data, to archives, to Aboriginal heritage, and considers the various roles and impacts prompted by their digital transformation and mobilization - from positive strengthening of families and identities to the riskier re-enactment of colonial stereotypes. She notes that 'visual technologies have always provided diverse and mutable conduits for transmitting images around the globe. Australia's first 1840s photographs of Aboriginal people, for example, were daguerreotypes, singular metal mirrors that could not be shared unless transformed into engravings and printed by a press into a publication'. While digitization offers powerful opportunities for re-connecting family networks and telling the truth of Indigenous experience, she describes the careful, intensive research and consultation that is required to do this without reifiying identity and tradition.

Finally, Ralph Mills' charming evocation of the mysteries of his mantelpiece, explores mass-produced objects, such as ceramic figurines, that may have been displayed on mantelpieces in working-class nineteenth and early twentieth-century houses, which he has encountered in archaeological contexts around Manchester in England. 'Above the hearth, at the heart of the home,' he writes, 'objects located on the mantelpiece could be said to be central in reflecting a number of aspects of the lives of those who placed them there'. Ralph relates how he constructed his own art installation to explore the ways that visitors to an art gallery in Manchester interacted with these small things, and how individuals might 'curate' collections in ways that transform mass produced items into 'objects of memory'.

As an assemblage these articles exhibit a careful consideration and questioning of exactly how materials and people constitute social worlds and relationships which sustain identity and memory and, in turn, the social and political structures or norms that these attachments invest in, stabilise and maintain. While each analysis works to reveal the histories and structures that might be concealed behind uncritical acceptance of 
ideas of 'possession and belonging', they all reflect the enchantment, pleasure or more ambivalent emotions that these authors derive from their work with small and forgotten things.

\section{ENDNOTES}

Daniel Miller, Stuff, Polity, Daniel Miller, London, 2009.

'Igor Kopytoff, 'The cultural biography of things: commoditization as process', in Arjun Appadurai (ed), The social life of things: commodities in cultural perspective, Cambridge University Press, Cambridge, 1986, pp64-91; Jody Joy, 'Reinvigorating object biography: reproducing the drama of object lives', World Archaeology, vol 41, 2009, pp540-556.

Kopytoff, op cit. Several recent museum projects have exploited this enduring fascination, for example the British Museum's The History of the World in 100 objects; see also Chris Gosden and Yvonne Marshall, 'The Cultural Biography of Objects', World Archaeology, vol 31, no 2, 1999, pp169-178. Joy, op cit.

${ }^{4}$ Haidy Geismar, 'The Photograph and the Malanggan: Rethinking Images on Malakula, Vanuatu', The Australian Journal of Anthropology, vol 20, 2009, pp48-73; Elizabeth Edwards, 'Objects of Affect: Photography Beyond the Image', Annual Review of Anthropology, vol 41, 2012, pp221-234

s Tony Bennett and Patrick Joyce (eds), Material Powers: Cultural studies, history and the material turn, Routledge, London and New York, 2010.

'Dianna Coole and Samantha Frost, 'Introducing the New Materialism', in Dianna Coole and Samantha Frost (eds), New Materialisms: Ontology, Agency, and Politics, Duke University Press, Durham, NC, 2010, p7; The revitalization of 'material culture studies' is also usefully reviewed in D. Hicks and M. Beaudry (eds), The Oxford Handbook of Material Culture Studies, Oxford University Press, Oxford, 2010.

For example, see Timothy Ingold, The perception of the environment: essays on livelihood, dwelling and skill, Routledge, London, 2000; Susanne Kuchler, 'Materiality and Cognition: the Changing Face of Things', in Daniel Miller (ed), Materiality, Duke University Press, 2005, pp206-231; Patricia Spyer (ed), Border Fetishisms: Material Objects in Unstable Spaces, Routledge, London, 1998.

s Amiria Henare, Martin Holbraad and Sari Wastell (eds), Thinking Through Things: Theorising Artefacts Ethnographically, Routledge, London, 2006.

- Zuzanna Jakubowski, 'Exhibiting Lost Love: The Relational Realism of Things', in Pamuk, The Museum of Innocence and Leanne Shapton, 'Important Artifacts', Realisms in Contemporary Culture: Theories, Politics, and Medial Configurations, vol 2, 2013, p124-145.

${ }^{10} \mathrm{ibid}, \mathrm{p} 135$.

"Roland Barthes, 'The Reality Effect', in Roland Barthes, The Rustle of Language, translated by Richard Howard, Hill and Wang, New York, 1986, pp141-148. See also Stephen Bann, The Inventions of History: Essays on the Representation of the Past, Manchester University Press, Manchester and New York, 1990.

${ }^{12}$ For overviews see Susan Matt, 'Current Emotion Research in History: Or, Doing History from the Inside Out', Emotion Review, vol 3, no 1, 2011, pp117-124; Anna Wierzbicka, 'The "History of Emotions" and the Future of Emotion Research', Emotion Review, vol 2, no 3, 2010, pp269-73; William M. Reddy, 'Historical Research on the Self and Emotions', Emotion Review, vol 1, no 4, 2009, pp302-315.

${ }^{13}$ Thomas Dixon refers to 'felt judgements'. See Thomas Dixon, From Passions to Emotions: The Creation of a Secular Psychological Category, Cambridge University Press, Cambridge, 2003; Barbara Rosenwein, 'Worrying about Emotions in History', The American Historical Review', vol 107, 2002, pp921-45.

${ }^{14}$ Affect is not merely a universal dimension of attachment; it is always already an attachment to, given specificity by a range of social encounters. Sara Ahmed, 'Happy Objects', in Melissa Gregg and Gregory J. Seigworth (eds), The Affect Theory 
Reader, Duke University Press, Durham and London, 2010, pp29-51.

${ }_{15}$ Sara Ahmed, The Cultural Politics of Emotion, Edinburgh University Press, Edinburgh, 2004, pp8-9; 83.

${ }^{16}$ See, for example, Susan Tarlow, 'The archaeology of emotion and affect', Annual Review of Anthropology, vol 41, 2012, pp169-85; Lynn Meskell, Archaeologies of Social Life: Age, Sex, Class Etcetera in Ancient Egypt, Blackwell, Oxford, 1999.

"See, for example, Bruno Latour and Steve Woolgar, Laboratory Life: the Social Construction of Scientific Facts, Sage, Los Angeles, 1979; Bruno Latour, Science in action: how to follow scientists and engineers through society, Harvard University Press, Cambridge Mass, 1987; Bruno Latour, We have never been modern, translated by Catherine Porter, Harvard University Press, Cambridge Mass, 1993.

${ }^{18}$ Lynn Meskell (ed), Archaeologies of Materiality, Blackwell, Oxford, 2005, p84; see also Susan Kus, 'Materials and Metaphors of Sovereignty in Central Madagascar', in Elizabeth DeMarrais, Chris Gosden and Colin Renfrew (eds), Re-thinking Materiality, McDonald Institute for Archaeology, Cambridge, 2005; Matt Edgeworth (ed), Ethnographies of Archaeological Practice: Cultural Encounters, Material Transformations, Altamira Press, Lanham, MD, 2006.

19 Yannis Hamilakis and Aris Anagnostopoulos, 'What is Archaeological Ethnography?',Public Archaeology, vol 8, nos 2-3, 2009, pp65-87.

${ }^{20}$ Clifford Geertz, 'Deep hanging out', The New York Review of Books, vol 45, no 16, 1998, pp69-72. 